\title{
Production and purification of polymerization- competent HIV-1 capsid protein p24 (CA) in NiCo21(DE3) Escherichia coli
}

Sin Yeang Teow ${ }^{1 \dagger}$, Siti Aisyah Mualif ${ }^{1 \dagger}$, Tasyriq Che Omarr ${ }^{1}$, Chew Yik Wei ${ }^{1}$, Narazah Mohd Yusoff ${ }^{2}$ and Syed A Ali ${ }^{{ }^{*}}$

\begin{abstract}
Background: HIV genome is packaged and organized in a conical capsid, which is made up of $\sim 1,500$ copies of the viral capsid protein p24 (CA). Being a primary structural component and due to its critical roles in both late and early stages of the HIV replication cycle, CA has attracted increased interest as a drug discovery target in recent years. Drug discovery studies require large amounts of highly pure and biologically active protein. It is therefore desirable to establish a simple and reproducible process for efficient production of HIV-1 CA.

Result: In this work, 6-His-tagged wild type CA from HIV-1 (NL4.3) was expressed in rare tRNA-supplemented NiCo21(DE3) Escherichia coli, and its production was studied in shake flask culture condition of expression. Influences of various key cultivation parameters were examined to identify optimal conditions for HIV-1 CA production. It was found that a culture temperature of $22^{\circ} \mathrm{C}$ and induction with $0.05 \mathrm{mM} \mathrm{IPTG}$ at the early stage of growth were ideal, leading to a maximum biomass yield when grown in Super broth supplemented with $1 \%$ glucose. With optimized culture conditions, a final biomass concentration of $\sim 27.7 \mathrm{~g} \mathrm{~L}^{-1}$ (based on optical density) was obtained in 12 hours post-induction, leading to a yield of about $\sim 170 \mathrm{mg} \mathrm{L}^{-1}$ HIV-1 CA. A two-step purification strategy (chitin beads + IMAC) was employed, which efficiently removed metal affinity resin-binding bacterial proteins that contaminate recombinant His-tagged protein preparation, and resulted in highly pure HIV-1 CA. The purified protein was capable of polymerization when tested in an in vitro polymerization assay.
\end{abstract}

Conclusions: By using this optimized expression and purification procedure, milligram amounts of highly pure and polymerization-competent recombinant HIV-1 CA can be produced at the lab-scale and thus used for further biochemical studies.

\section{Background}

Human immunodeficiency virus (HIV) causes acquired immunodeficiency syndrome (AIDS), a progressive immune disorder that allows life-threatening opportunistic infections, cardiovascular diseases, and cancers to thrive. The capsid protein p24 (CA) plays seminal roles in both late and early stages of the HIV replication cycle [1]. HIV-1 CA is considered an important target for developing novel drugs to treat AIDS. For example, a small molecule, CAP-1, and two versions of a peptide inhibitor, CAI and NYAD-1, have been reported that target HIV-1 CA

\footnotetext{
*Correspondence: ali2@amdi.usm.edu.my

${ }^{\dagger}$ Equal contributors

'Oncological and Radiological Sciences, Advanced Medical and Dental Institute, Universiti Sains Malaysia, Bertam, 13200 Kepala Batas, Pulau Pinang, Malaysia

Full list of author information is available at the end of the article
}

in vitro and interfere with its function in infected cells [2-4]. In another study, two small compounds PF-3450074 and PF-3759857 have shown to be active against HIV-1 in low $\mu \mathrm{M}$ concentration and latter (PF-3759857) against HIV-2 too [5]. More recently, compounds derived from benzodiazepines (BD) and the benzimidazoles (BM) series of chemicals have shown to prevent virion release and inhibited the formation of the mature capsid [6]. These studies require milligram quantities of the $\mathrm{CA}$ in soluble and active form. However, high commercial cost may limit its use in studies carried out at academic level.

The HIV-1 CA has been produced in bacterium Escherichia coli [7-11], yeast Pichea pastoris [12], plants [13-15], and baculovirus-insect cells [16]. However, existing methodologies rely on sequence modifications and several purification rounds involving precipitation

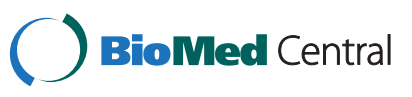


and multiple chromatographic steps to obtain CA from host' contaminating proteins.

Due to the presence of rare codons and low solubility of over-expressed recombinant protein, it has been challenging to obtain large quantities of HIV-1 CA. The aim of this study was to establish a convenient and relatively fast purification procedure for obtaining large amounts of biologically active HIV-1 CA at the laboratory scale. The expression and purification method described here is simple, expresses protein from the wild type $p 24$ gene, and yields up to $170 \mathrm{mg}$ of highly pure HIV-1 CA suitable for polymerization experiments.

\section{Methods}

\section{Bacterial strains, plasmids, and media}

The E. coli strains DH5 $\alpha$ (NEB \#C2987H) and NiCo21 (DE3) (NEB \#C2529H) were used for cloning and expression experiments respectively. Bacteria were aerobically grown in LB broth $\left(10 \mathrm{~g} \mathrm{~L}^{-1}\right.$ bacto-tryptone; $5 \mathrm{~g} \mathrm{~L}^{-1}$ yeast extract; $5 \mathrm{~g} \mathrm{~L}^{-1} \mathrm{NaCl}$; $\left.\mathrm{pH} 7.0\right)$ or on LB agar $\left(10 \mathrm{~g} \mathrm{~L}^{-1}\right.$ bacto-tryptone; $5 \mathrm{~g} \mathrm{~L}^{-1}$ yeast extract; $5 \mathrm{~g} \mathrm{~L}^{-1} \mathrm{NaCl}$; $15 \mathrm{~g} \mathrm{~L}^{-1}$ Agar; $\mathrm{pH}$ 7.0) at various temperatures and in the absence or presence of Ampicillin $\left(100 \mu \mathrm{g} \mathrm{mL}^{-1}\right)$ and/or Chloramphenicol $\left(25 \mu \mathrm{g} \mathrm{mL}{ }^{-1}\right)$. Bacterial strains were stored in LB broth plus $50 \%$ glycerol at $-80^{\circ} \mathrm{C}$. In some experiments, NiCo21(DE3) were transformed with rare tRNA supplementing plasmids pACYC-RIL (Stratagene), pRARE2 (Novagen), and pLysSRARE2 (Novagen). In some experiments, NiCo21(DE3) were grown in $\mathrm{M} 9$ broth $\left(0.5 \mathrm{~g} \mathrm{~L}^{-1} \mathrm{NaCl} ; 1 \mathrm{~g} \mathrm{~L}^{-1} \mathrm{NH}_{4} \mathrm{Cl} ; 3 \mathrm{~g} \mathrm{~L}^{-1} \mathrm{KH}_{2} \mathrm{PO}_{4} ; 6.78 \mathrm{~g} \mathrm{~L}^{-1}\right.$ $\mathrm{Na}_{2} \mathrm{HPO}_{4} ; 2 \mathrm{mM} \mathrm{MgSO}$; $0.1 \mathrm{mM} \mathrm{CaCl}_{2} ; 10 \mathrm{~g} \mathrm{~L}^{-1}$ glucose. $\mathrm{pH}$ 7.0), Super broth (32 $\mathrm{g} \mathrm{L}^{-1}$ bacto-tryptone; $20 \mathrm{~g} \mathrm{~L}^{-1}$ yeast extract; $5 \mathrm{~g} \mathrm{~L}^{-1} \mathrm{NaCl}$; $\mathrm{pH}$ 7.0), or Terrific broth (12 $\mathrm{g} \mathrm{L}^{-1}$ bacto-tryptone; $24 \mathrm{~g} \mathrm{~L}^{-1}$ yeast extract; $8 \mathrm{~mL} \mathrm{~L}^{-1}$ glycerol; $2.2 \mathrm{~g} \mathrm{~L}^{-1} \mathrm{KH}_{2} \mathrm{PO}_{4} ; 9.4 \mathrm{~g} \mathrm{~L}^{-1} \mathrm{~K}_{2} \mathrm{HPO}_{4}$. $\mathrm{pH}$ 7.0).

Construction of plasmid expressing HIV-1 CA (pSA-HP24-6His) Construction scheme of pSA-Hp24-6His is given in Figure 1A.

\section{Preparation of insert (p24 with 5' Ndel and 3' Sacl restriction enzyme sites)}

The pNL4.3 plasmid (GenBank accession no. M19921) harboring complete genome of HIV-1 NL4.3 was obtained through the NIH AIDS Reagent Program and used as the template for PCR amplification of p24 gene encoding 231 residues of wild-type capsid protein p24. The p24 gene was PCR amplified using forward primer P24-F-NdeI (5' GGTGGTCATATGCCTATAGTGCAG AACCTCCAG 3', NdeI restriction site is in italics) and reverse primer P24-R-SacI (5' GGTGGTGAGCTC CAAAACTCTTGCTTTATGGCC 3', SacI restriction site is in italics) with high fidelity Pfu DNA polymerase (Thermo Scientific \#EP0572) following manufacturer's supplied protocol. The PCR product (714 bp amplicon) was purified using NucleoSpin ${ }^{\circ}$ Gel and PCR Clean-up kit (MACHEREY-NAGEL GmbH \& Co \#740609) and restricted with NdeI (NEB \# R0111L) and SacI (NEB \#R0156L) restriction enzymes following manufacturer's supplied protocol.

\section{Preparation of vector}

Expression vector pMXB10 (NEB) was amplified by PCR using primers pMXB10-F-SacI-6His (5' CTCGAGCTC CACCATCACCATCACCATTGACTGCAGGAAGGGG ATC 5', SacI restriction site is in italics) and pMXB10R-NdeI (5' GGCTCTTCCCATATGTATATCTCC 3', $N d e$ I restriction site is in italics) with $P f u$ polymerase. The PCRed plasmid $(5.914 \mathrm{~kb})$ was gel purified using NucleoSpin ${ }^{\circ}$ Gel and PCR Clean-up kit and restricted with NdeI and SacI restriction enzymes.

Insert and vector were ligated in a 1:3 molar ratio using T4 DNA ligase (NEB \#M0202S), transformed in chemically competent $\mathrm{DH} 5 \alpha$ E. coli cells, and selected on LB-agar plates (containing 100 ug $\mathrm{mL}^{-1}$ Ampicillin) after $18 \mathrm{~h}$ incubation at $30^{\circ} \mathrm{C}$. A total of 10 randomly selected bacterial colonies were subjected to colony PCR using a vector-specific primer T7Up-F (5' GATCCCGC GAAATTAATACG $3^{\prime}$ ) and an insert-specific primer P24-R (5' GTGGAGCTCCAAAACTCTTGC 3'). Amplification of a 806 bp PCR product will be confirmatory for the successful cloning of P24 insert in pSA vector. Plasmid DNA was isolated from 3 colony PCR-positive clones and subjected to restriction analysis and DNA sequencing. We named this recombinant plasmid pSAHp24-6His.

\section{Expression of capsid protein p24 in pSA-HP24-6His- transformed NiCo21(DE3) E. coli}

Sequencing-confirmed pSA-Hp24-6His was transformed into chemically competent $\mathrm{NiCo21(DE3)} \mathrm{E} \mathrm{coli} \mathrm{and}$ transformants were selected on LB-Agar containing $100 \mu \mathrm{g} \mathrm{mL}^{-1}$ Ampicillin. For expression, a single colony from a freshly streaked $(\sim 18 \mathrm{~h})$ plate was inoculated in $10 \mathrm{~mL}$ of Ampicillin-supplemented LB broth. The starter culture was grown at $30^{\circ} \mathrm{C}$ while shaking at $250 \mathrm{rpm}$ until the $\mathrm{OD}_{600}$ was approximately 1 . The bacterial cells were centrifuged at $3000 \times \mathrm{g}$ for $10 \mathrm{~min}$, re-suspend in fresh LB broth, and used to inoculate the main culture at $1: 20$ dilution $\left(0.5 \mathrm{OD}_{600}\right)$. The culture was grown at $30^{\circ} \mathrm{C}$ while shaking at $250 \mathrm{rpm}$ until the OD600 reached to $0.5-0.6$. The cultures were then equilibrated to induction temperature $\left(30,22\right.$, or $\left.18^{\circ} \mathrm{C}\right)$ and induced with various concentrations of Isopropylthio- $\beta$-galactoside (IPTG). Induced cultures were grown for different time lengths (6 hours at $30^{\circ} \mathrm{C} ; 12$ hours at $22^{\circ} \mathrm{C} ; 16$ hours at $18^{\circ} \mathrm{C}$ ) and bacterial cells were pelleted by centrifugation at $5000 \times \mathrm{g}$ for 10 minutes in pre-weighed centrifuge tubes/bottles. 


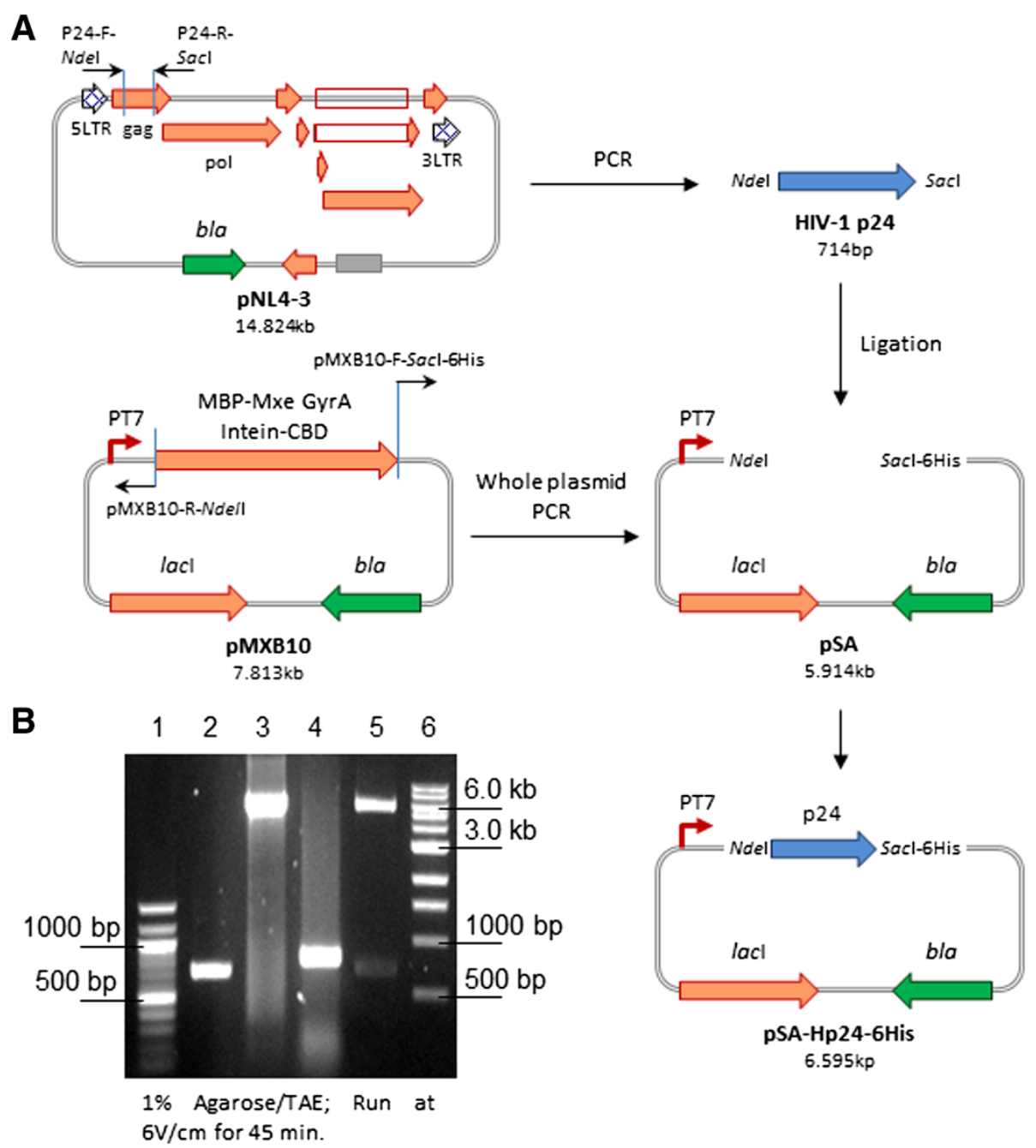

Figure 1 Construction and verification of pSA-Hp24-6His vector. We PCR amplified the p24 gene from pNL4.3 and cloned at Ndel/Sacl restriction sites in inversely PCRed pMXB10 vector (A). Agarose gel electrophoresis analysis (B). Lane 1, 100 bp DNA ladder (NEB\#N0467S); Lane 2, PCR amplified 714 bp p24; Lane 3, inversely PCRed 5.91 kb pSA vector; Lane 4, representative colony PCR (806 bp); Lane 5, restriction analysis of pSA-Hp24-6His with Ndel/Sacl (5.89 kb vector backbone + 702 bp insert) ; Lane 6, 1 kb DNA ladder (NEB \#N0468S).

Expression of HIV-1 CA in NiCo21(DE3) transformed with PACYC-RIL, pRARE2, and pLysSRARE2

The NiCo21(DE3) were individually transformed with pACYC-RIL, pRARE2, and pLysSRARE2 vectors and the transformants were selected on LB agar plates containing $25 \mu \mathrm{g} \mathrm{mL} \mathrm{m}^{-1}$ Chloramphenicol. Transformants were grown out and competent cells were prepared following Inoue's protocol [17]. The pACYC-RIL, pRARE2, and pLysSRARE2-containing NiCo21(DE3) were then transformed with pSA-Hp24-6His vector and the transformants were selected on LB agar plates containing Ampicillin $\left(100 \mu \mathrm{g} \mathrm{mL} \mathrm{m}^{-1}\right)$ and Chloramphenicol $(25 \mu \mathrm{g}$ $\left.\mathrm{mL}^{-1}\right)$. Cultures were grown in presence of both the antibiotics and the expression protocol given above was essentially followed. To study the effect of various culture media on the expression of HIV-1 CA, cultures were grown in 1\% glucose-supplemented M9 minimal broth, LB Broth, Terrific Broth, and Super Broth essentially following the expression protocol given above.

\section{Cell lysis and protein extraction}

To every 1 gram of bacterial cell pellet, $4 \mathrm{~mL}$ of B-PER extraction reagent (Thermo Scientific \#78248) supplemented with DNAse I (Thermo Scientific \#90083) and protease cocktail (Thermo Scientific \#87785) was added. The mixture was incubated at $22^{\circ} \mathrm{C}$ for $30 \mathrm{~min}$ on a nutator shaker. Soluble and insoluble proteins were partitioned by centrifuging bacterial cell lysate at 15,000 $\times \mathrm{g}$ for 5-10 minutes at $4^{\circ} \mathrm{C}$. Clear supernatant containing soluble proteins was passed through $0.45 \mu$ membrane (Millipore \#HPWP04700) and used for immobilizedmetal affinity chromatography (IMAC). Insoluble lysed 
bacterial biomass was resuspended to original volume with phosphate buffered saline (PBS). Both, soluble and insoluble fractions were stored in small aliquots at $-80^{\circ} \mathrm{C}$ for further analysis.

\section{Protein assays, SDS-PAGE, and immunoblotting}

Total protein was quantitated using Qubit $^{\circ}$ Protein Assay Kit (Life Technologies - Invitrogen \# Q33211) in a Qubit fluorometer (Life Technologies - Invitrogen). For SDS-PAGE, protein fractions were mixed with $5 \mathrm{X}$ reducing sample buffer (Thermo Scientific \#39000), resolved on $12 \%(\mathrm{w} / \mathrm{v})$ polyacrylamide gels, and detected with Coomassie blue G250 as described previously [18]. For immunoblot analysis, proteins were electroblotted onto the Hybond ECL nitrocellulose membrane (GE Healthcare Life Sceinces \#RPN2020D). The membrane was washed in Tris-buffered saline (TBS) for $5 \mathrm{~min}$, blocked with 5\% nonfat milk in TTBS (TBS with $0.1 \%$ Tween 20) for $1 \mathrm{~h}$ by shaking at room temperature, processed for immunoblotting using either primary antiHis MAb (Thermo Scientific \#MA1-21315) or anti-p24 MAb (NIH AIDS reagent program \# 71-31) with shaking at $4^{\circ} \mathrm{C}$ overnight followed by a secondary HRPconjugated $\operatorname{IgG}(\mathrm{H}+\mathrm{L})$ antibody (Thermo Scientific \# 32430). Protein bands were detected by SuperSignal West Pico Chemiluminescent substrate (Thermo Scientific \# 34080) followed by image capture using FluorChem M Imager (ProteinSimple). Band intensities were determined using software AlphaView SA version 3.4.0. (ProteinSimple).

\section{Purification of HIV-1 CA}

Recombinant HIV-1 CA was purified in two steps. First, the soluble protein fraction was pre-adsorbed on chitin resin (NEB \#S6651) to get rid of bacterial Histidine-rich proteins. An appropriate amount of Chitin beads was added into a plastic chromatography column (BioRad \#732-1010) and equilibrated in two resin-bed volumes of Equilibration/Wash Buffer (50 mM sodium phosphate, $500 \mathrm{mM}$ sodium chloride, $10 \mathrm{mM}$ imidazole; $\mathrm{pH}$ 7.4). Soluble protein fraction was diluted with an equal volume of Equilibration/Wash Buffer and added to the equilibrated chitin beads $(1 \mathrm{ml}$ of chitin resin for each volume of lysate corresponding to 1 gram of NiCo21(DE3) cell pellet). The column was then placed on an end-over-end rotator and revolved for 30 minutes at $4^{\circ} \mathrm{C}$. Void volume containing target protein was eluted by gravity flow and used for IMAC.

For IMAC, HisPur ${ }^{\mathrm{rm}}$ Cobalt resin (Thermo Scientific \#89965) was used following manufacturer's protocol. Briefly, an appropriate amount of cobalt resin was added in $15 \mathrm{~mL}$ centrifuge tube and washed with two resin-bed volumes of Equilibration/Wash Buffer. The chitin bead pre-adsorbed soluble protein fraction was combined with equilibrated cobalt resin and mixed on an endover-end rotator for 60 minutes at $4^{\circ} \mathrm{C}$. The resin was then washed with Equilibration/Wash Buffer until the absorbance at $280 \mathrm{~nm}$ reached to the baseline. Bound protein was eluted using one resin-bed volume of Elution Buffer (50 mM sodium phosphate, $500 \mathrm{mM}$ sodium chloride, $150 \mathrm{mM}$ imidazole; $\mathrm{pH}$ 7.4). This step was repeated 2-3 times while saving individual fractions. Fractions were analyzed by SDS-PAGE/Western blot, dialyzed against phosphate buffered saline (PBS) using Slide-A-Lyzer Dialysis Cassettes, 7K MWCO (Thermo Scientific \#66710) and stored at $-80^{\circ} \mathrm{C}$ in small aliquots.

\section{Purification of HIV-1 CA on FPLC}

The HIV-1 CA was purified using TALON ${ }^{\circ}$ Superflow $^{\text {Tw }}$ cobalt-based IMAC column on an FPLC system (AKTA purifier 900, GE). All buffers were prepared in deionized water; filtered through $0.2 \mu \mathrm{m}$ membrane, and degassed for $15 \mathrm{~min}$. Column and all buffers were equilibrated to room temperature before use. The column was connected to the chromatography system by 'drop-to-drop' method to avoid introducing air into the system. The column was equilibrated with 5 column volumes (CVs) of Binding buffer (50 mM sodium phosphate, $300 \mathrm{mM}$ $\mathrm{NaCl}, \mathrm{pH}$ 7.4). Sample was diluted 1:1 with Binding buffer and transferred into large-volume sample loop (Superloop $50 \mathrm{~mL}, \mathrm{GE}$ ) for sample loading. After sample loading, the column was washed with $10 \mathrm{CVs}$ of Wash buffer (50 mM sodium phosphate, $300 \mathrm{mM} \mathrm{NaCl}, 5 \mathrm{mM}$ imidazole, $\mathrm{pH}$ 7.4) until the absorbance reached a steady baseline. Protein was eluted in a linear imidazole gradient $(5-150 \mathrm{mM}$ in $50 \mathrm{mM}$ sodium phosphate, $300 \mathrm{mM}$ $\mathrm{NaCl}, \mathrm{pH}$ 7.4) and collected in $1 \mathrm{~mL}$ fractions. The purified fractions were then analyzed by SDS-PAGE, dialyzed against phosphate buffered saline (PBS) using Slide-ALyzer Dialysis Cassettes, 7K MWCO (Thermo Scientific $\# 66710$ ), and stored at $-80^{\circ} \mathrm{C}$ in small aliquots. The column was washed with $5 \mathrm{CVs}$ of $20 \%$ ethanol and stored at $4^{\circ} \mathrm{C}$.

\section{Polymerization assay for HIV-1 CA}

A turbidometric assay was used to study in vitro polymerization of HIV-1 CA as described previously [19]. Final concentration of purified CA $(40-80 \mu \mathrm{M})$ was mixed with $50 \mathrm{mM}$ sodium phosphate buffer (pH8.0) in a total volume of $250 \mu \mathrm{L}$. The CA assembly was induced by adding $250 \mu \mathrm{L}$ of $2.0 \mathrm{M} \mathrm{NaCl}$ (final concentration) in $50 \mathrm{mM}$ sodium phosphate buffer, pH8.0. The mixture $(500 \mu \mathrm{L})$ was briefly vortexed, immediately transferred to a silica cuvette (10 $\mathrm{mm}$ path length), and spectrophotometrically read at $350 \mathrm{~nm}$ wavelength at room temperature. The absorbance measurements were made every 10s for up to $60 \mathrm{~min}$. The assembly rate was then set by plotting the absorbance versus time. 
For polymerization inhibition, $50 \mu \mathrm{M}$ purified CA was mixed with various concentrations $(1,5,10 \mu \mathrm{M})$ of CAspecific anti-p24 antibody (NIH AIDS reagent program \# 71-31) in $50 \mathrm{mM}$ sodium phosphate buffer (pH8.0) in a total volume of $250 \mu \mathrm{L}$. The reaction was incubated at room temperature for 30 minutes. The CA assembly was induced by adding $250 \mu \mathrm{L}$ of $2.0 \mathrm{M} \mathrm{NaCl}$ and polymerization monitored as described above. AntiAcetylcholinesterase (AChE) antibody, clone AE-1 (Merck Millipore \# MAB303) was used as negative control at a final concentration of $20 \mu \mathrm{M}$.

\section{Immunization and HIV-1 CA-specific antibody detection}

Two 6-weeks old female BALB/c mice were individually primed by a single intradermal injection of $100 \mu \mathrm{g} / 100 \mu \mathrm{L}$ $\mathrm{CA}$ in complete Freund's Adjuvant (CFA). Mice were boosted with three successive injections of $100 \mu \mathrm{g} / 100 \mu \mathrm{L}$ $\mathrm{CA}$ in Incomplete Freund's Adjuvant (IFA) at an interval of two weeks. Serum was prepared from blood samples and serially diluted from $1: 1000$ to $1: 100,000$ and subjected to ELISA and used for immunoblot analysis.

\section{T cell culture and transfection}

The 293T cells (ATCC \#CRL-11268) were maintained in DMEM (Sigma \#D5030) supplemented with 10\%FBS (Life technologies \# 16000-044) at $37^{\circ} \mathrm{C}$ in presence of $5 \% \mathrm{CO}_{2}$. Cells $\left(1 \times 10^{5}\right)$ were transfected with $0.5 \mu \mathrm{g}$ of pNL4.3 (prepared using Endotoxin-free plasmid, Macherey Nagel \# 740420) using $2 \mu \mathrm{L}$ of X-tremeGene HP transfection reagent (Roche \#06366236001) following supplied protocol. Cells were harvested 48 hours post-transfection, lysed with M-Per lysis reagent (Thermo Scientific \#78503), and subjected to SDSPAGE/Western blot analysis.

\section{Results}

\section{Construction of plasmid expressing HIV-1 CA}

To express HIV-1 capsid protein p24, we chose prokaryotic expression vector pMXB10 due to its ability of high level heterologous protein expression in BL21(DE3) $E$. coli. The 'ATG' initiation codon is the part of NdeI restriction site and located at an optimal distance of $8 \mathrm{nu}$ cleotides from the ribosome binding site (RBS). We did not aim to express capsid protein p24 as a fusion protein with intein-CBD (for which the $\mathrm{pMXB10}$ vector was originally designed) and therefore, we took out the entire $1.938 \mathrm{~kb}$ MBP-Mxe GyrA intein-CBD fragment by $P C R$ amplification of the pMXB10. We also introduced a SacI restriction site followed by 21 nucleotides encoding a $6 \mathrm{His}$ tag and a stop codon as shown in Figure 1A. Cloning of a $714 \mathrm{bp}$ amplicon encoding 231 residues of wildtype HIV-1 capsid protein p24 at NdeI/SacI sites resulted in a $6.595 \mathrm{~kb}$ recombinant plasmid pSA-Hp246His. We verified the pSA-Hp24-6His construct by restriction enzyme analysis (Figure 1B) and DNA sequencing (data not shown). The mRNA sequence encoding the capsid protein p24 is transcribed from an inducible $\mathrm{T} 7$ promoter and the resulting protein has a 6 His tag at its carboxy-terminal to facilitate IMACmediated purification.

\section{Expression of HIV-1 CA in NiCo21(DE3) E. coli}

We used NiCo21 (DE3) to express 6His-tagged HIV-1 CA using shake flask culture condition of expression. Plasmids containing retroviral sequences are instable in E. coli [20], especially when grown at $37^{\circ} \mathrm{C}$. Therefore, we cultured the pSA-Hp24-6His-trandformed NiCo21 (DE3) at $30^{\circ} \mathrm{C}$ until the $\mathrm{OD}_{600}$ reached to 0.5-0.6. We then induced the cultures with $0.4 \mathrm{mM}$ IPTG and continued incubation at $30^{\circ} \mathrm{C}$ for another 6 hours while shaking. When subjected to SDS-PAGE analysis, the overexpressed CA appeared as approximately $24 \mathrm{kDa}$ band in the IPTG-induced fractions (Figure 2, left panel). Overexpressed CA was present in both, insoluble (Figure 2, lane IS) and soluble fraction (Figure 2, lane S). Immunoblot analysis with anti-CA antibody confirmed that the overexpressed protein was HIV-1 CA (Figure 2, right panel). On the western blot, just above the CA band, a 25-26 kDA band was observed. Either it is a host protein that binds to CA or it is a product of transcriptional read-through. Since the anti-p24 antibody does not bind to the host proteins, we anticipate that this anti-p24 reactive $25-26 \mathrm{kDA}$ band is a product of transcriptional read-through.

\section{Optimization of IPTG concentration and induction temperature}

Since induction with lower IPTG concentrations and/or at lower temperature may result in improved solubility of overexpressed protein [21], we tested various IPTG concentrations $(0-0.4 \mathrm{mM})$ and induction temperatures (30, 22, and $\left.18^{\circ} \mathrm{C}\right)$. Expression of HIV-1 CA was optimal at $0.05 \mathrm{mM}$ of IPTG as determined by western blot analysis (Figure 3A). More overexpressed protein was present in soluble fraction compared to in-soluble fraction when cultures were induced with $0.05 \mathrm{mM}$ IPTG and grown at $18^{\circ} \mathrm{C}$ for 16 hours (Figure 3B, lanes $8 \& 9$ ). However, larger amounts of CA were present in cultures induced with $0.05 \mathrm{mM}$ IPTG and grown at $22^{\circ} \mathrm{C}$ for 12 hours (Figure 3B, lanes 5\&6).

\section{Effect of rare tRNA supplementation on HIV-1 CA production in $\mathrm{NiCo21}$ (DE3) E. coli}

Over-expression of recombinant proteins in E. coli may be significantly reduced or even stalled if the ORF that codes for the protein uses "rare" codons that are infrequently used by $E$. coli $[21,22]$. When subjected to 'rare' codon analysis, $576 \mathrm{bp}$ ORF coding for HIV-1 CA found 


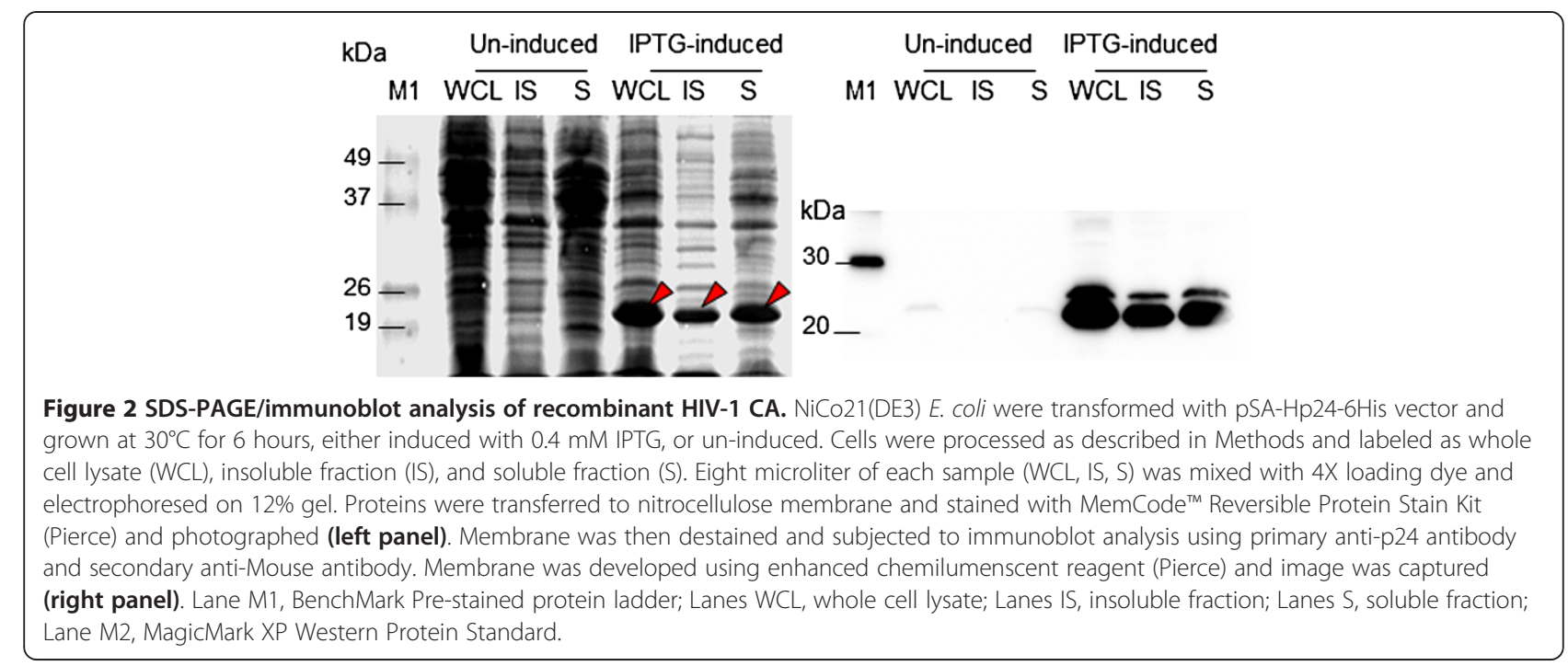

to contain (a) three rare codons (AGG, AGA, CGA) for arginine at positions 44, 59, 62, 94, 105, 116, 124, 129, 135, 191; (b) one rare codon (CTA) for leucine at positions 18, 134, 173; (c) one rare codon (ATA) for isoleucine at positions $66,77,96,103,115$; and (d) one rare codon (CCC) for proline at positions 122, 186 (Figure 4A). To find out whether CA expression could be improved by supplementing NiCo21(DE3) cells with plasmids expressing rare tRNA, we transformed NiCo21 (DE3) with pACYC-RIL, pRARE2, and pLysSRARE2. The pACYC-RIL plasmid supplies tRNA for four rare codons (AUA, AGG, AGA, CUA), whereas pRARE2 for seven rare codons (AUA, AGG, AGA, CUA, CCC, CGG, and GGA). In addition to seven rare codons,

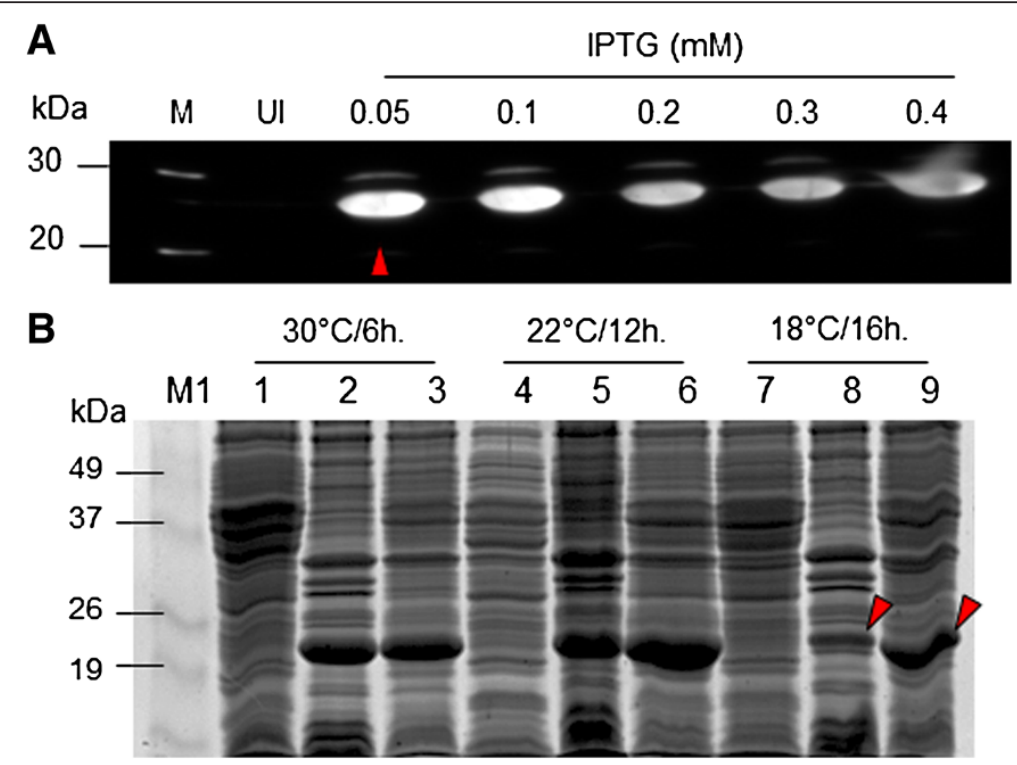

Figure 3 Optimization of IPTG concentration and induction temperature for the expression of HIV-1 CA. Determination of optimal inducer concentration: The pSA-Hp24-6His-transformed NiCo21 (DE3) E. coli cultures $\left(0.6 \mathrm{OD}_{600}\right)$ were added with varying concentrations $(0-0.4 \mathrm{mM})$ of IPTG and incubated at $30^{\circ} \mathrm{C}$ for 6 hours. Eight micro liter of cultures were mixed with $4 \mathrm{X}$ loading dye, boiled, and electrophoresed on $12 \%$ gels. Proteins were transferred to NC membranes and immunoblot analysis was carried out as described in Methods. (A). Determination of optimal induction temperature: The pSA-Hp24-6His-transformed NiCo21(DE3) E.coli cultures $\left(0.6 \mathrm{OD}_{600}\right)$ were induced with $0.05 \mathrm{mM}$ IPTG and incubated at 30, 22, and 18 C for 6, 12, and 18 hours respectively. Cultures were then processed to obtain insoluble (IS) and soluble (S) fractions and electrophoresed as described in Methods. Gels were stained with Coomassie Blue G250 and photographed (B). Lane M1, BenchMark Pre-stained protein ladder; Lane 1: Un-induced culture at $30^{\circ} \mathrm{C}$ (soluble); Lane 2, IPTG-induced culture at $30^{\circ} \mathrm{C}$ (insoluble); Lane 3, IPTG-induced culture at $30^{\circ} \mathrm{C}$ (soluble); Lane 4: Un-induced culture at $22^{\circ} \mathrm{C}$ (soluble); Lane 5, IPTG-induced culture at $22^{\circ} \mathrm{C}$ (insoluble); Lane 6, IPTG-induced culture at $22^{\circ} \mathrm{C}$ (soluble); Lane 7: Un-induced culture at $18^{\circ} \mathrm{C}$ (soluble); Lane 8, IPTG-induced culture at $18^{\circ} \mathrm{C}$ (insoluble); Lane 9, IPTG-induced culture at $18^{\circ} \mathrm{C}$ (soluble). 


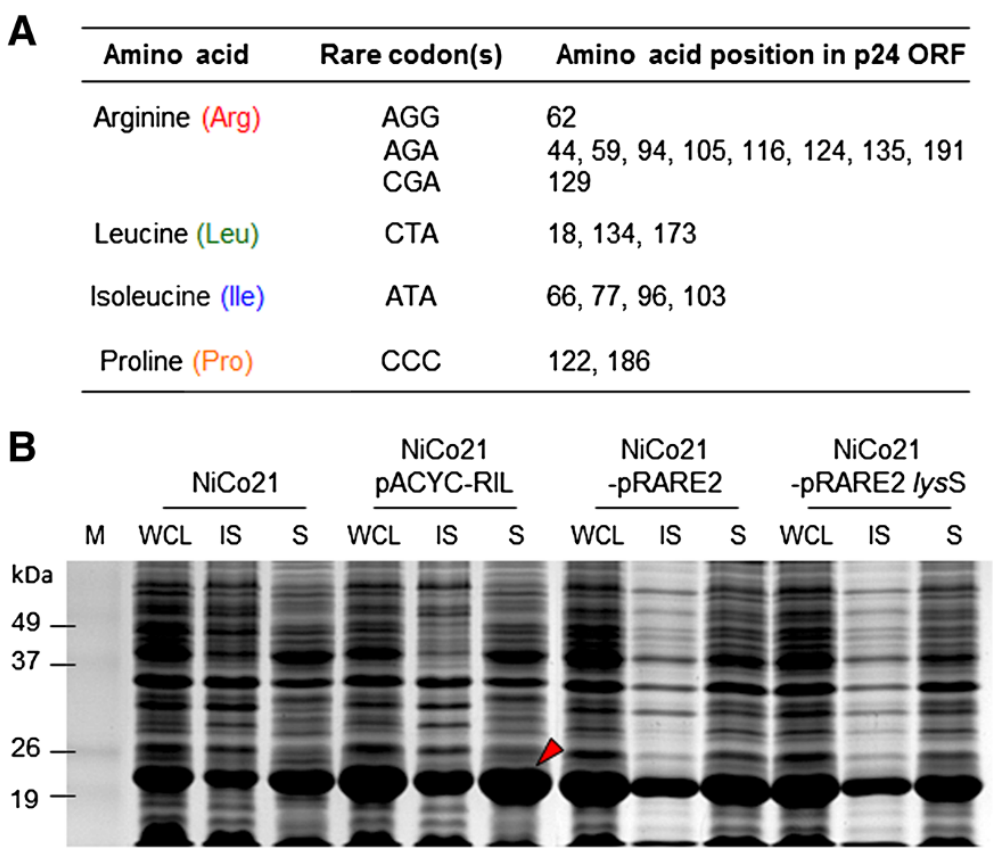

Figure 4 Effect of rare tRNA supplementation on HIV-1 CA expression in NiCo21(DE3) E. coli. Rare codon analysis of open reading frame (ORF) coding for HIV-1 p24 gene (A). NiCo21(DE3) E. coli were transformed with PACYC-RIL or pRARE2 or pRARE2-lysS and subsequently transformed with pSA-Hp24-6His vectors and selected on LB + Cam + Amp plates. Cultures were grown in presence of Cam $+\mathrm{Amp}$ at $22^{\circ} \mathrm{C}$ for 12 hours, either induced with $0.05 \mathrm{mM} \mathrm{IPTG}$, or un-induced. Cultures were processed to obtain whole cell lysate (WCL), insoluble (S), and soluble (S) fractions. Samples were electrophoresed on 12\% gel, stained with Coomassie Blue G250, and photographed (B). Lane M, BenchMark Pre-stained protein ladder; Lanes WCL, whole cell lysate; Lanes IS, insoluble fraction; Lanes S, soluble fraction.

transformation with pLysSRARE2 also results in lower background expression due to the presence of T7 lysozyme. When expressed in the presence of rare tRNA supplying plasmids, there was an improvement in CA expression (Figure 4B). However, overexpressed protein proportionally ended up in the insoluble fractions suggesting that bacterial protein folding machinery was saturated when CA was expressed in the presence of rare tRNA. We did not see a significant change in CA expression between the NiCo21(DE3) containing pACYCRIL and pRARE2/pLysSRARE2. This suggests that supplementation with 4 rare codons was sufficient to improve CA expression. When compared side-by-side, we found NiCo21(DE3)/pACYC-RIL produced highest amount of CA (Figure 4B). Expression of CA in the presence or absence of rare tRNA had minimal effect on the growth of bacteria as determined by the total biomass yield (9.1 $\mathrm{g} \mathrm{L}^{-1}$ for NiCo21(DE3) and $8.96 \mathrm{~g} \mathrm{~L}^{-1}$ for NiCo21(DE3) with pACYC-RIL). These experiments were repeated at $18^{\circ} \mathrm{C}$ but distribution of recombinant protein between soluble and insoluble fraction remained the same, and incubation at lower temperature did not result in more soluble CA (data not shown).

We also studied the effect of cultivation medium composition both on the growth of the NiCo21(DE3)pACYC-RIL and the production of the HIV-1 CA. Cells were grown in M9, LB, Super, and Terrific broths at $22^{\circ} \mathrm{C}$ and in the presence of $1 \%$ glucose. Protein expression was induced by adding $0.05 \mathrm{mM}$ IPTG when the cells reach to $0.5 \mathrm{OD}_{600}$. Cells were harvested 12 hours post-induction and analyzed by SDS-PAGE. The highest amount of biomass ( $27.7 \mathrm{~g} \mathrm{~L}^{-1}$ culture) was obtained in Super broth followed by Terrific broth $\left(\sim 18.3 \mathrm{~g} \mathrm{~L}^{-1}\right)$, and LB broth $\left(16.7 \mathrm{~g} \mathrm{~L}^{-1}\right)$. Growth in M9 minimal broth resulted in the lowest amount of biomass production $\left(7.5 \mathrm{~g} \mathrm{~L}^{-1}\right)$. Expression of CA was similar in LB, Super, and Terrific broth, and lowest in M9 minimal broth when equal amount of biomass subjected to SDS-PAGE analysis (Figure 5A). However, since largest biomass was produced in Super broth, it resulted into highest amount of HIV-1 CA produced from $1 \mathrm{~L}$ culture (Figure $5 \mathrm{~B}$ ).

Addition of $2-3 \%$ ethanol in culture medium [23,24] and incubation at $42^{\circ} \mathrm{C}$ [25] leads to the overexpression of chaperons, which in turn results in improved folding and enhanced solubility of certain proteins. We tested these conditions to improve the solubility of CA but did not observe any effect (data not shown). When analyzed using Wilkinson-Harrison statistical solubility model [26], the HIV-1 CA-6His found to have a CV-CV' value of 0.57 and 63.8 percent chance of insolubility when overexpressed in E. coli. In our case, percentage solubility based on the band density (density of soluble band 

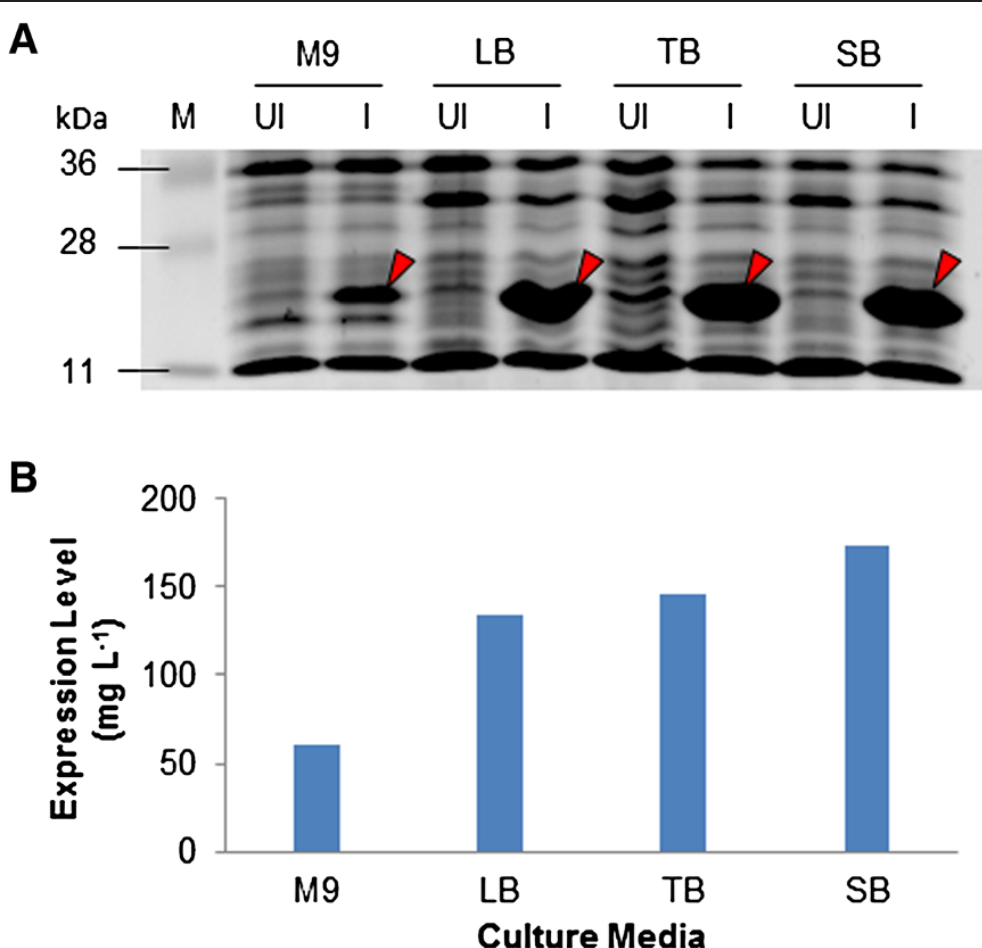

Figure 5 Effect of cultivation medium composition on production of HIV-1 CA. NiCo21(DE3)-pACYC-RIL expressing HIV-1 CA were grown in various cultivation media supplemented with $1 \%$ glucose and $0.05 \mathrm{mM} \mathrm{IPTG}$ at $22^{\circ} \mathrm{C}$ for 12 hours. Cultures were adjusted to $1.5 \mathrm{OD}_{600}$ (to normalize the biomass) and 8 uL of culture was analyzed using SDS-PAGE (A). M, Pre-stained protein ladder; Lanes UI, un-induced; Lanes I, IPTG-induced. Comparison of HIV-1 CA production levels obtained using different growth media (B). Cells were harvested, lysed, and subjected to Chitin/IMAC purification. Eluted protein was quantitated and HIV-1 CA produced from $1 \mathrm{~L}$ of biomass was calculated.

divided by the density of the soluble plus insoluble bands) was $60.65 \%$ and $65.35 \%$ for $\mathrm{NiCo} 21(\mathrm{DE} 3)$ and NiCo21(DE3)-pACYC-RIL respectively. Based on our results and Wilkinson-Harrison statistical solubility model, we anticipate that CA may not be expressed $100 \%$ in soluble state, unless it is expressed as fusion protein with solubility enhancing partner such as maltose binding protein (MBP), NusA etc.

\section{Purification of HIV-1 CA from pSA-Hp24-6His-transfected NiCo21(DE3) E. coli}

BL21(DE3) is a widely used E. coli strain for recombinant protein overexpression. Like other E. coli strains, BL21(DE3) contains a number of host proteins that are rich in nonconsecutive histidine residues. These histidine-rich proteins co-purify during IMAC procedures rendering recombinant protein preparations impure. The NiCo21(DE3) is a derivative of BL21(DE3) in which three histidine-rich proteins (sly D, can, $\operatorname{arn} \mathrm{A})$ are tagged with chitin binding domain and in one $(g \operatorname{lm} \mathrm{S})$, the histidine-rich motifs are replaced with alanine [27]. Pre-adsorption of bacterial cell lysates on chitin beads results in the removal of major host histidine-rich proteins. Depleted fractions are then subjected to IMAC, which yields highly pure 6His-tagged recombinant protein preparations. We lysed the pSA-Hp24-6Histransformed NiCo21(DE3) and subjected the lysates to IMAC ( $\mathrm{Co}^{2+}$ beads) alone, chitin beads alone, and chitin beads + IMAC purification. A considerable amount of contaminating proteins (shown by the arrowheads) copurified with HIV-CA when purified using IMAC alone (Figure 6A, lane 1) or chitin beads alone (Figure 6A, lane 2). On the other hand, the HIV-1 CA was purified with un-noticeable (on Coomassie-stained gels) host protein contamination (Figure 6A, lane 3) when subjected to chitin beads + IMAC purification strategy. In some experiments, we first performed IMAC, and imidazole eluate was then treated with chitin beads to remove the host histidine-rich proteins. However, results were not as good, perhaps due to the presence of $150 \mathrm{mM}$ imidazole in the eluate (results not shown).

To further demonstrate the purification efficiency, we treated the HIV-1 CA overexpressing NiCo21(DE3) lysates with chitin beads and subjected the chitin beadtreated lysates to TALON $^{\circ}$ Superflow $^{\text {Tx }}$ cobalt-based IMAC column on FPLC system. The recombinant CA was eluted with a linear $(5-150 \mathrm{mM})$ imidazole gradient. Elution of CA was monitored by absorbance at $280 \mathrm{~nm}$. A representative FPLC chromatogram shows a single peak eluting at $150 \mathrm{mM}$ imidazole, spanning A6-A11 


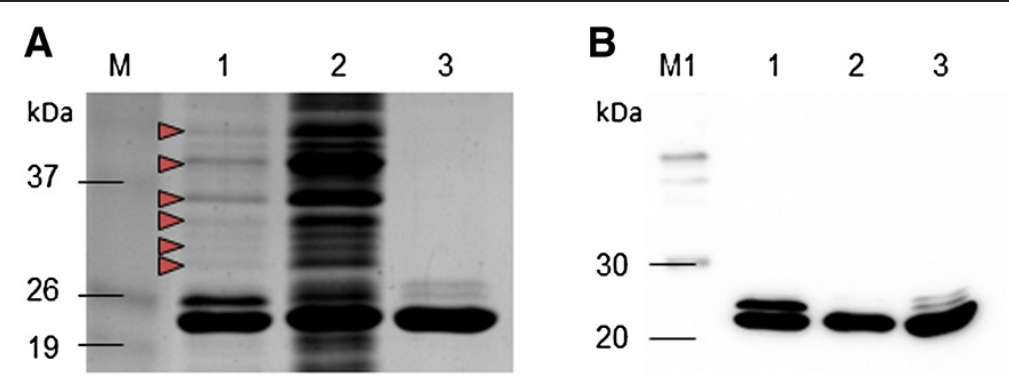

Figure 6 Purification of HIV-1 CA expressed in NiCo21(DE3) E. coli. NiCo21(DE3)-pACYC-RIL expressing HIV-1 CA were grown in presence of $0.05 \mathrm{mM} \mathrm{IPTG}$ at $22^{\circ} \mathrm{C}$ for 12 hours and processed to purify recombinant protein using $\mathrm{Co}^{2+}$ resin, chitin resin, and $\mathrm{Chitin}^{2} \mathrm{Co}^{2+}$ resins. Sample collected during the procedure were analyzed by SDS-PAGE (A) and western blot (B). Lane M, BenchMark Pre-stained protein ladder; Lane M1, MagicMark XP Western Protein Standard; Lane 1, CA purified on $\mathrm{Co}^{2+}$ resin; Lane 2, CA purified on chitin resin; Lane 3, CA sequentially purified on chitin and $\mathrm{Co}^{2+}$ resins. Red arrowheads show contaminating proteins when CA was purified using $\mathrm{Co}^{2+}$ resin alone (Lane 1).

fractions. We subjected these fractions to SDS-PAGE analysis, which shows a single $24 \mathrm{kDa}$ band in all six fractions. The eluted protein in these fractions did not appear to be contaminated with other proteins (Figure 7).

Using the purification scheme described above, we yielded $>6 \mathrm{mg}$ of purified HIV-1 CA from $1 \mathrm{~g}$ biomass of pSA-Hp24-6His-transformed NiCo21(DE3)/pACYC-RIL when propagated in super broth and induced with $0.05 \mathrm{mM}$ IPTG for $12 \mathrm{~h}$ at $21^{\circ} \mathrm{C}$. The average yield and percentage recovery of recombinant HIV-1 CA from three independent $100 \mathrm{~mL}$ expression cultures is given in the Table 1.

\section{Antigenicity of recombinant HIV-1 CA}

This work is part of a project in which we are generating anti-CA antibody phage display library (manuscript in preparation). The ELISA plates coated with recombinant CA were used to determine the serum titer of

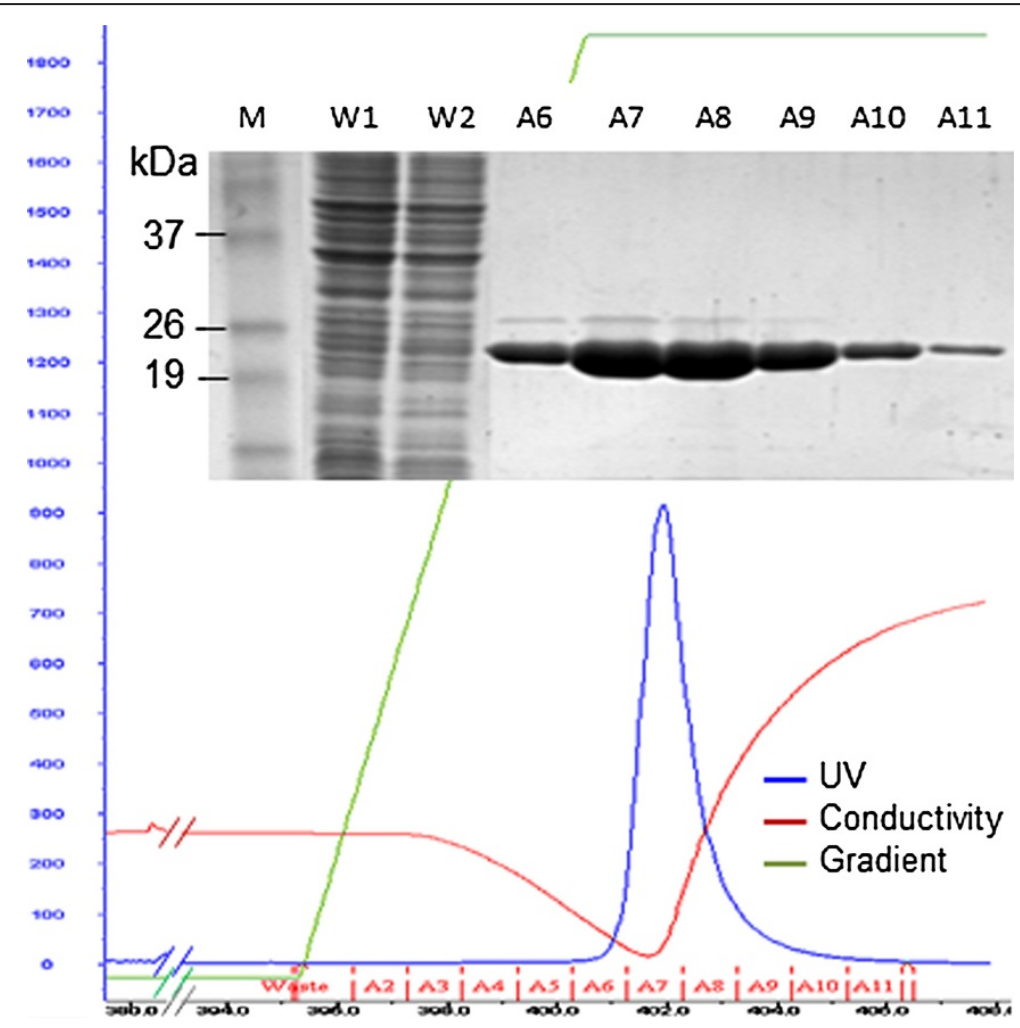

Figure 7 FPLC and electrophoretic analysis of HIV-1 CA. HIV-1 CA was purified using TALON ${ }^{\circledR}$ Superflow ${ }^{\text {TM }}$ cobalt-based IMAC column on an FPLC system. SDS/PAGE (12\%) analysis results (inset) of the eluted fractions as shown in the FPLC chromatogram. Fractions A6 to A11 were pooled as the high purity product. Lane M, BenchMark Pre-stained protein ladder; Lanes W1/W2, unbound protein in wash fractions; Lanes A6-A11, CA eluted in imidazole gradient. 
Table 1 Yield and percentage recovery of recombinant HIV-1 CA

\begin{tabular}{lccc}
\hline Sample & Total protein $\mathbf{( m g )}$ & HIV CA $(\mathbf{m g})$ & Purity $(\%)$ \\
\hline Soluble lysate & 288 & 39 & 13.5 \\
Chitin beads & 166 & 25 & 15.06 \\
IMAC & 17.5 & 17 & 97.1 \\
\hline
\end{tabular}

NiCo21(DE3)-pACYC-RIL expressing HIV-1 CA were grown in super broth the presence of $0.05 \mathrm{mM} \mathrm{IPTG}$ at $22^{\circ} \mathrm{C}$ for 12 hours and processed to purify recombinant protein as described in Methods. Quantities of recombinant HIV-1 CA are based on average values from three independent $100 \mathrm{~mL}$ expression cultures. HIV-1 CA was quantified by densitometry of bands on a western blots and the Qubit fluorometric total protein assay.

immunized mice prior to harvesting anti-CA antibody mRNA from the spleens. Serum was diluted 1:10, 1:100, $1: 1000,1: 10,000$, and 1:100,000 respectively and assayed using indirect ELISA. Pre-immune serum was used as negative control. As shown in Figure 8A, the titer was higher than 1:100,000.

The antiserum was also used for immunoblot analysis of the cell lysates of pNL4.3-transfected/HIV-1 (NL4.3)producing 293T cells and mock-transfected 293T cells (as negative control). Recombinant HIV-1 CA was used as the positive control. The antiserum specifically reacted with pNL4.3-transfected 293T cells and recombinant CA but not with the un-transfected 293T cells (Figure $8 \mathrm{~B}$ ). These results show that the recombinant CA had correct immunogenicity profile.

\section{Polymerization competency of HIV-1 CA}

To show that purified CA was biologically active (capable of polymerizing), we subjected the recombinant protein to an in vitro polymerization assay. The recombinant CA was allowed to polymerize under high salt conditions and the change in turbidity (measured at $350 \mathrm{~nm}$ ) over time (up to $60 \mathrm{~min}$ ) was recorded. Kinetic traces of CA exhibited a typical sigmoidal timedependent protein aggregation/polymerization curve for
80, 60 and $50 \mu \mathrm{M}$ CA (Figure 9A). Curves obtained for $40 \mu \mathrm{M}$ CA showed a lag phase (Figure 9A) that was due to the low concentration of CA and characteristic of a nucleation step. These results showed that purified CA was biologically active and suitable to study polymerization/inhibition of polymerization of the intact capsid protein (CA) of HIV-1 into mature capsid-like particles.

To further demonstrate that the purified HIV-CA could be used for the identification of CA assembly inhibitors, we incubated $50 \mu \mathrm{M}$ HIV-1 CA with varying concentrations $(1,5,10 \mu \mathrm{M})$ of CA-specific anti-p24 antibody. Incubation of HIV-CA with anti-p24 antibody resulted in a dose-dependent inhibition of CA polymerization. Incubation with $10 \mu \mathrm{M}$ anti-p24 resulted in a complete inhibition of CA assembly, whereas $5 \mu \mathrm{M}$ antibody delayed the rate of CA polymerization (Figure 9B). To rule out the possibility of non-specific inhibition of CA assembly due to the presence of large antibody molecules in the reaction mix, we incubated the HIV-1 CA with anti-AChE antibody. Presence of $20 \mu \mathrm{M}$ (twice as much as anti-p24) anti-AChE had no effect on CA polymerization (Figure 9B). This suggests that CA polymerization inhibition in the presence of anti-p24 was due to the specific binding to the CA molecules.

\section{Discussion}

Emergence of anti-retroviral (ARV) drug-resistant quasispecies of HIV is a major obstacle in the effective treatment of AIDS. To cope with the drug resistant mutants, there is a constant need of developing newer and better therapeutic regimens against novel targets. Due to its important role in both late and early stages of the HIV replication cycle, $\mathrm{CA}$ has attracted considerable attention as a potential target in recent years. Chemical compounds and peptides interfering with the capsid
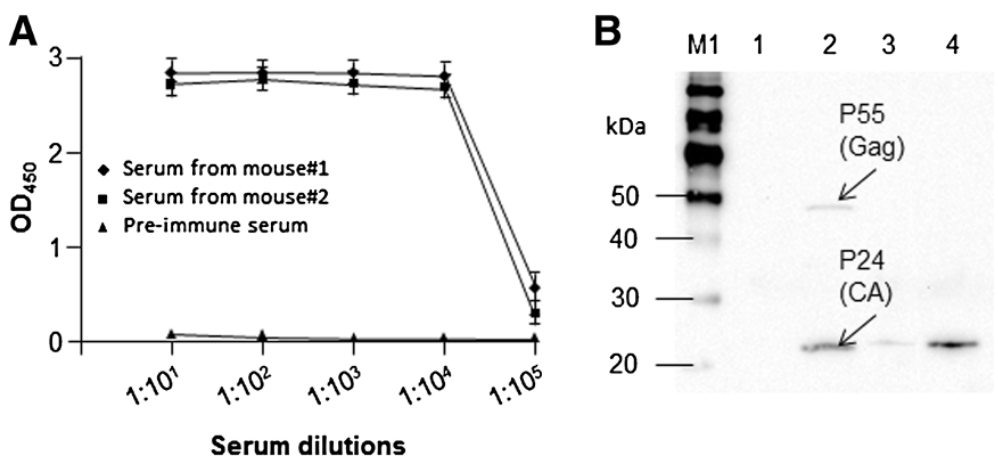

Figure 8 Antigenicity of HIV-1 CA. We immunized mice with purified CA as described in Methods. The sera from immunized mice were serially diluted and subjected to indirect ELISA. The pre-immune serum served as the negative control (A). 293T cells were transfected with the pNL4-3 plasmid and cell lysates were analyzed by SDS-PAGE and Western blotting using serum from CA-immunized mice (B). Lane M1, MagicMark XP Western Protein Standard; Lane 1, mock-transfected 293T cell lysate; Lane 2, pNL4.3-transfected 293T cell lysate; Lane 3, purified CA (10 ng); Lane 4, purified CA (100 ng). 

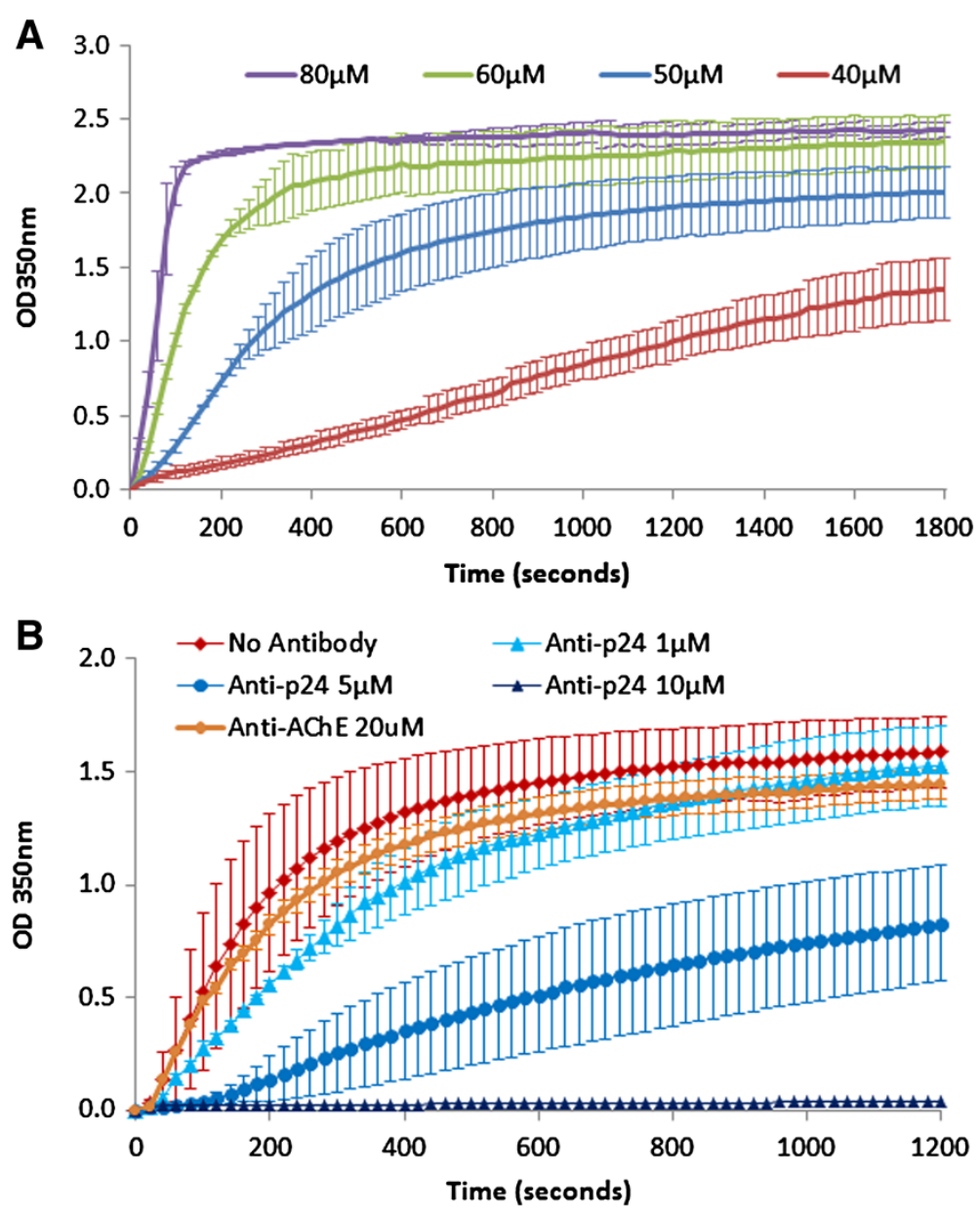

Figure 9 Polymerization competency of HIV-1 CA. Purified CA (40-80 $\mu \mathrm{M})$ was mixed with $50 \mathrm{mM}$ sodium phosphate buffer (pH 8.0) and the polymerization was induced by the addition of $2.0 \mathrm{M} \mathrm{NaCl}$ solution. Polymerization was monitored by measuring absorbance at $350 \mathrm{~nm}$ every $10 \mathrm{~s}$ for up to $60 \mathrm{~min}$ (A). To further confirm that purified HIV-1 CA could be used for the identification of CA assembly inhibitors, we incubated $50 \mu \mathrm{M}$ HIV-1 CA with varying concentrations (1,5,10 $\mu \mathrm{M})$ of CA-specific anti-p24 MAb. Anti-Acetylcholinesterase antibody was used as a negative control (B)

assembly have shown to alter the infectivity of the virions and prevented their release from the cells [2-6]. These studies typically need milligram quantities of highly pure and polymerization-competent CA. Due to the high cost of commercially available CA, it would by highly desirable to produce it in-house.

Bacterium Escherichia coli is by far the most robust and economical in vivo system for the production of heterologous recombinant proteins in scalable quantities. Unfortunately, HIV-1 CA expresses poorly in $E$. coli due to its use of rare codons. Codon optimization is one possibility but it can prove tedious and costly. Furthermore, codon optimization does not guarantee high yields of soluble protein since bacterial folding machinery can get saturated due to the high turnover rate of protein synthesis, and produced protein can end up in the inclusion bodies [22]. An alternative of codon optimization is to transform the expression host with plasmids expressing rare tRNA. We anticipated that the use of a host strain supplemented with rare tRNA should result in higher yields of recombinant CA. Indeed, when expressed in NiCo21(DE3) containing rare tRNA-expressing plasmids pACYC-RIL and/or pRARE2, there was a significant improvement in the yield of recombinant HIV-1 CA. Plasmid pACYC-RIL supplies tRNA for arginine (AGA, AGG), isoleucine (AUA), and leucine (CUA) whereas pRARE2 supplies tRNA for arginine (AGA, AGG, CGG), isoleucine (AUA), leucine (CUA), proline (CCC), and glycine (GGA). However, protein expression was indifferent between the bacteria carrying pACYC-RIL or pRARE2. The highest number of rare codons in $p 24$ gene are for arginine (10 rare codons) followed by isoleucine (4 rare codons), leucine ( 3 rare codons), and proline ( 2 rare codons). It appears that 
tRNA supplementation for frequently used rare codons (arginine, isoleucine, and leucine) was sufficient to improve the protein yield.

Lab-scale purification of HIV-1 CA has also been hampered due to its poor solubility when overexpressed in E. coli. While it is possible to purify functional proteins from the inclusion bodies, it is a time consuming process and increases the cost of production. Attempts have been made to improve the solubility of HIV-1 CA by gene modification. For instance, it has been reported that solubility can be improved by introducing a Cysteine at 230 position, which makes a disulfide bond with Cys210 and promotes proper folding of recombinant CA [10]. It was also shown that the substitutions of certain amino acids had no effect on the immunogenicity of the recombinant protein [10]. However, whether these changes would have altered the polymerization competence of CA was not discussed. Since the recombinant CA produced in present study was intended to be used for generating/screening anti-CA phage display library and screening polymerization inhibiting single chain $\mathrm{Fv}$ antibodies, we used wild-type sequence. By systematically optimizing the culture conditions (IPTG concentration, temperature, culture medium composition), we managed to produce milligram quantities of recombinant protein in soluble state. It would be interesting to note that as little as $0.05 \mathrm{mM}$ IPTG was sufficient to induce the recombinant protein expression. Use of less IPTG in the culture medium would also result in the economical production of recombinant protein. Even though the ratio of soluble $v s$ insoluble protein was highest for cultures incubated at $18^{\circ} \mathrm{C}$, the final yield was greatest when the cultures were incubated at room temperature $\left(22 \pm 2^{\circ} \mathrm{C}\right)$. Room temperature incubation is also convenient and economical compared to $18^{\circ} \mathrm{C}$, which needs refrigerated incubators.

IMAC is one of the most popular methods for the purification of poly-histidine-tagged recombinant proteins. Unfortunately, poly-histidine-tagged recombinant proteins that are isolated by IMAC are frequently contaminated with endogenous $E$. coli metal binding proteins. Some 17 E. coli IMAC contaminating proteins have been described, 15 of which elute from Ni-NTA at $>55 \mathrm{mM}$ imidazole. These contaminating proteins include CRP, Fur, ArgE, DnaK, SlyD, GlmS, GlgA, ODO1, ODO2, Can (YadF), ArnA (YfbG), AceE, GroES, and GroEL. Since His-tagged proteins are typically eluted between $60-150 \mathrm{mM}$ imidazole, the IMAC contaminants co-elute rendering target protein preparations impure. Secondary chromatographic steps, e.g., size exclusion, protein specific (Heparin affinity), immunoaffinity, and dual affinity tag chromatography have been suggested. However, these additional procedures result in more operative time, additional cost, and lower overall yields.
To address this problem, Robichon et al. has described NiCo21(DE3) strain specifically engineered to minimize major E. coli protein contaminants (SlyD, GlmS, Can, ArnA) of IMAC fractions [27]. This strain expresses the endogenous proteins SlyD, Can, and ArnA fused at their $\mathrm{C}$ terminus to a chitin binding domain (CBD) and the protein GlmS, with six surface histidines replaced by alanines [27]. Desired recombinant protein(s) produced in NiCo21(DE3) are separated from CBD-tagged IMAC contaminating proteins by adsorbing them on chitin beads.

As shown in the results, purification of $\mathrm{HIV}-1 \mathrm{CA}$ using IMAC alone resulted in CA contaminated with several host proteins. When the soluble lysate was pretreated with chitin beads and then subjected to IMAC, highly pure CA was obtained. The only downside of this purification scheme is the employment of two successive purification steps, one using chitin beads, and second using IMAC. However, this scheme of purification is still better than those where additional chromatographic steps are employed. Chitin beads are cheap, can be regenerated multiple times, and above all, compatible with commonly used IMAC buffers. The loss of desired protein in chitin bead pre-treatment was minimal in our case. While in process of preparing this manuscript, Andersen et al. reported the use of LOBSTR, a derivative of E. coli BL21(DE3) that carries gnomically modified copies of arnA and slyD [28]. Proteins translated from these modified genes exhibited reduced affinities to IMAC, resulting in higher purity of overexpressed heterologous proteins. While only two of the four major metal binding proteins are modified for reduced affinity to IMAC, use of LOBSTR has shown to result in significantly improved purification and without the additional chitin resin adsorption step. This will both reduce the cost and time.

We showed that the recombinant HIV-1 CA produced in this work was biologically active in the polymerization assay. We also showed that the polymerization of HIV-1 CA could be inhibited following its incubation with CAspecific anti-p24 antibody. We incubated the CA with an unrelated anti-AChE antibody and demonstrated that CA polymerization was specifically inhibited by the anti-p24 antibody. These data indicate that CA polymerization assay could be used to screen CA polymerizationinhibiting antibodies. CA is an intracellular target and therefore off-limit to antibodies that normally do not penetrate into the cytoplasm. However, strategies are being devised to develop antibodies capable of crossing the plasma membrane and interacting with intracellular targets [29-31].

A recent report has described the purification of HIV-1 CA using its intrinsic tendency to polymerize and depolymerize. Isolation of protein using this technique 
did result in the purification of highly pure and polymerization competent CA [11]. While the technique is novel, it still involves several steps, from ammonium sulfate precipitation to polymerization/de-polymerization, multiple dialyses, and anion exchange chromatography. The route we took to purify CA is conventional but it involves fewer steps and is highly reproducible. Use of approach described here has resulted in as much protein yield as compared to the method reported by Hung et al. (>6 mg versus 5-7 mg from each one gram of bacterial biomass). By cultivating the bacteria in Super broth, twice as much capsid protein can be produced from $1 \mathrm{~L}$ of the culture.

\section{Conclusion}

In the current paper, we report on a methodical analysis of HIV-1 CA expression in E. coli based on the combination of expression vector, $E$. coli strain selection, and analysis of cultivation conditions and fermentation broth. The simple expression and purification procedure described in this work resulted in the production of highly pure and biologically active HIV-1 CA in good yields for potential use in drug discovery, diagnostics, and in vaccine production.

\section{Competing interests}

The authors declare that they have no competing interests.

\section{Authors' contributions}

ST, SM, and SA carried out the construction of recombinant plasmids, performed optimization experiments, and drafted the manuscript. ST and SM have contributed equally. TO and CW performed expression and purification experiments. SA, and NY conceived the study and helped to draft the manuscript. All authors read and approved the final manuscript.

\section{Acknowledgements}

This work was supported by the FRGS grant (203/CIPPT/6711206) from Ministry of Higher Education (MOHE), Government of Malaysia to Syed A Ali and Narazah Mohd Yusoff. Sin Yeang Teow is a recipient of MyPhD scholarship (KPT (B) 890416075223) under MyBrain15 program of MOHE and part of his research is supported by AMDI, USM under a Research Student Fund (USM/IPPT/2000/G-2/xiv) and RU-PRGS grant (1001/CIPPT/846048) from USM. Siti Aisyah Mualif is a recipient of MOHE scholarship (KPT (BS) 841003015520) and part of her research is funded by AMDI, USM (USM/IPPT/ 2000/G-2/xiv). Tasyriq Che Omar is a recipient of ASTS (Academic Staff Training Scheme) of Universiti Sains Malaysia together with SLAB from Ministry of Education, Malaysia.

\section{Author details}

Oncological and Radiological Sciences, Advanced Medical and Dental Institute, Universiti Sains Malaysia, Bertam, 13200 Kepala Batas, Pulau Pinang, Malaysia. ${ }^{2}$ Regenerative Medicine, Advanced Medical and Dental Institute, Universiti Sains Malaysia, 13200 Kepala Batas, Pulau Pinang, Malaysia.

Received: 24 August 2013 Accepted: 28 November 2013 Published: 4 December 2013

\section{References}

1. Mascarenhas AP, Musier-Forsyth K: The capsid protein of human immunodeficiency virus: interactions of HIV-1 capsid with host protein factors. FEBS J 2009, 276(21):6118-6127.

2. Tang C, Loeliger E, Kinde I, Kyere S, Mayo K: Antiviral inhibition of the HIV-1 capsid protein. J Mol Biol 2003, 327:1013-1020.
3. Sticht J, Humbert M, Findlow S, Bodem J, Muller B: A peptide inhibitor of HIV-1 assembly in vitro. Nat Struct Mol Biol 2005, 12:671-677.

4. Zhang $\mathrm{H}$, Zhao $\mathrm{Q}$, Bhattacharya S, Waheed AA, Tong X: A cell-penetrating helical peptide as a potential HIV-1 inhibitor. J Mol Biol 2008, 378:565-580.

5. Blair WS, Pickford C, Irving SL, Brown DG, Anderson M, Bazin R, Cao J, Ciaramella G, Isaacson J, Jackson L, Hunt R, Kjerrstrom A, Nieman JA, Patick AK, Perros M, Scott AD, Whitby K, Wu H, Butler SL: HIV capsid is a tractable target for small molecule therapeutic intervention. PLoS Pathog 2010, 6(12):e1001220

6. Lemke CT, Titolo S, von Schwedler U, Goudreau N, Mercier JF, Wardrop E, Faucher AM, Coulombe R, Banik SS, Fader L, Gagnon A, Kawai SH, Rancourt J, Tremblay M, Yoakim C, Simoneau B, Archambault J, Sundquist WI, Mason SW: Distinct effects of two HIV-1 capsid assembly inhibitor families that bind the same site within the $\mathrm{N}$-terminal domain of the viral CA protein. J Virol 2012, 86(12):6643-6655.

7. Spence RP, Jarvill WM, Ferns RB, Tedder RS, Parker D: The cloning and expression in Escherichia coli of sequences coding for p24, the core protein of human immunodeficiency virus, and the use of the recombinant protein in characterizing a panel of monoclonal antibodies against the viral p24 protein. J Gen Virol 1989, 70(Pt 11):2843-2851.

8. Ehrlich LS, Krausslich HG, Wimmer E, Carter CA: Expression in Escherichia coli and purification of human immunodeficiency virus type 1 capsid protein (p24). AIDS Res Hum Retroviruses 1990, 6(10):1169-1175.

9. Gross I, Hohenberg H, Kräusslich HG: In vitro assembly properties of purified bacterially expressed capsid proteins of human immunodeficiency virus. Eur J Biochem 1997, 249(2):592-600.

10. Zhang B, Liu D, Bao Z, Chen B, Li C, Jiang H, Wang X, Mi Z, An X, Lu J, Tong $Y$ : High level soluble expression, one-step purification and characterization of HIV-1 p24 protein. Virol J 2011, 8:316

11. Hung M, Niedziela-Majka A, Jin D, Wong M, Leavitt S, Brendza KM, Liu X, Sakowicz R: Large-scale functional purification of recombinant HIV-1 capsid. PLoS One 2013, 8(3):e58035.

12. Jiang WZ, Jin NY, Li ZJ, Zhang LS, Wang HW, Zhang YJ, Han WY: Expression and characterization of gag protein of HIV-1(CN) in Pichia pastoris. J Virol Methods 2005, 123(1):35-40.

13. Zhang GG, Rodrigues $L$, Rovinski B, White KA: Production of HIV-1 p24 protein in transgenic tobacco plants. Mol Biotechnol 2002, 20(2):131-136.

14. Meyers A, Chakauya E, Shephard E, Tanzer FL, Maclean J, Lynch A Williamson AL, Rybicki EP: Expression of HIV-1 antigens in plants as potential subunit vaccines. BMC Biotechnol 2008, 8:53.

15. Lindh I, Wallin A, Kalbina I, Sävenstrand H, Engström P, Andersson S, Strid A: Production of the p24 capsid protein from HIV-1 subtype C in Arabidopsis thaliana and Daucus carota using an endoplasmic reticulum-directing SEKDEL sequence in protein expression constructs. Protein Expr Purif 2009, 66(1):46-51.

16. Mills $H R$, Jones IM: Expression and purification of p24, the core protein of HIV, using a baculovirus-insect cell expression system. AIDS 1990, 4(11):1125-1131.

17. Inoue $\mathrm{H}$, Nojima $\mathrm{H}$, Okayama $\mathrm{H}$ : High efficiency transformation of Escherichia coli with plasmids. Gene 1990, 96(1):23-28.

18. Lawrence AM, Besir HU: Staining of proteins in gels with coomassie G-250 without organic solvent and acetic acid. J Vis Exp 2009, 14(30):1350.

19. Abdurahman S, Vegvari A, Youssefi M, Levi M, Hoglund S, Andersson E, Horal P, Svennerholm B, Balzarini J, Vahlne A: Activity of the small modified amino acid a-hydroxy glycineamide on in vitro and in vivo human immunodeficiency virus type I capsid assembly and infectivity. Antimicrob Agents Chemother 2008, 52(10):3737-3744

20. Trinh T, Jessee J, Bloom F, Hirsch V: STBL2: an Escherichia coli strain for the stable propagation of retroviral clones and direct repeat sequences. Focus 1994, 16:78-80.

21. Sørensen HP, Mortensen KK: Advanced genetic strategies for recombinant protein expression in Escherichia coli. J Biotechnol 2005, 115(2):113-128.

22. Angov E, Hillier CJ, Kincaid RL, Lyon JA: Heterologous protein expression is enhanced by harmonizing the codon usage frequencies of the target gene with those of the expression host. PLoS One 2008, 3(5):e2189.

23. Thomas JG, Baneyx F: Divergent effects of chaperone overexpression and ethanol supplementation on inclusion body formation in recombinant Escherichia coli. Protein Expr Purif 1997, 11(3):289-296.

24. Winter J, Neubauer P, Glockshuber R, Rudolph R: Increased production of human proinsulin in the periplasmic space of Escherichia coli by fusion to DsbA. J Biotechnol 2001, 84(2):175-185. 
25. Chen J, Acton TB, Basu SK, Montelione GT, Inouye M: Enhancement of the solubility of proteins overexpressed in Escherichia coli by heat shock. J Mol Microbiol Biotechnol 2002, 4(6):519-524.

26. Wilkinson DL, Harrison RG: Predicting the solubility of recombinant proteins in Escherichia coli. Biotechnology (N Y) 1991, 9(5):443-448.

27. Robichon C, Luo J, Causey TB, Benner JS, Samuelson JC: Engineering Escherichia coli BL21(DE3) derivative strains to minimize E. coli protein contamination after purification by immobilized metal affinity chromatography. Appl Environ Microbiol 2011, 77(13):4634-4646.

28. Andersen KR, Leksa NC, Schwartz TU: Optimized E. coli expression strain LOBSTR eliminates common contaminants from His-tag purification. Proteins 2013, 15. Epub 2013 Aug 23.

29. Lim KJ, Sung BH, Shin JR, Lee YW, da Kim J, Yang KS, Kim SC: A cancer specific cell-penetrating peptide, BR2, for the efficient delivery of an scFv into cancer cells. PLoS One 2013, 8(6):e66084.

30. Weisbart RH, Gera JF, Chan G, Hansen JE, Li E, Cloninger C, Levine AJ, Nishimura RN: A cell-penetrating bispecific antibody for therapeutic regulation of intracellular targets. Mol Cancer Ther 2012, 11(10):2169-2173.

31. Marschall ALJ, Frenzel A, Schirrmann T, Schüngel M, Dübel S: Targeting antibodies to the cytoplasm. MAbs 2011, 3(1):3-16.

doi:10.1186/1472-6750-13-107

Cite this article as: Teow et al:: Production and purification of polymerization-competent HIV-1 capsid protein p24 (CA) in NiCo21 (DE3) Escherichia coli. BMC Biotechnology 2013 13:107.

\section{Submit your next manuscript to BioMed Central and take full advantage of:}

- Convenient online submission

- Thorough peer review

- No space constraints or color figure charges

- Immediate publication on acceptance

- Inclusion in PubMed, CAS, Scopus and Google Scholar

- Research which is freely available for redistribution 